\title{
Description of a ZZ/ZW sex chromosome system in Thoracocharax cf. stellatus (Teleostei, Characiformes, Gasteropelecidae)
}

\author{
Margarida Lima Carvalho ${ }^{1}$, Claudio Oliveira ${ }^{2}$ and Fausto Foresti ${ }^{2}$ \\ ${ }^{1}$ Departamento de Ciências da Natureza, Universidade Federal do Acre, Rio Branco, AC, Brazil. \\ ${ }^{2}$ Departamento de Morfologia, Instituto de Biociências, Universidade Estadual Paulista, \\ Botucatu, SP, Brazil.
}

\begin{abstract}
The family Gasteropelecidae is composed of three genera and eight species. This study shows that Thoracocharax cf. stellatus has $2 n=52$ chromosomes for both sexes. The five males studied showed 8 metacentric, 16 submetacentric, 4 subtelocentric, and 24 acrocentric chromosomes; the seven females showed only one submetacentric chromosome, belonging to pair 11, and one extra acrocentric chromosome, smaller than all the other chromosomes, characterizing the presence of a ZZ/ZW sex chromosome system in this species. Nucleolus organizing regions (NORs) were detected on the short arms of the subtelocentric chromosome pair 13. Constitutive heterochromatin was identified at pericentromeric and terminal positions in almost all chromosomes. The $\mathrm{W}$ chromosome was almost entirely heterochromatic, except for a small terminal euchromatic segment. The analyses of the amount of nuclear DNA found $2.18 \pm 0.09 \mathrm{pg}$ of DNA per diploid nucleus, without significant differences between sexes. A discussion about the evolution of the sex chromosomes in this group is presented.
\end{abstract}

Key words: sex chromosomes, ZW, DNA content, fish, evolution.

Received: April 2, 2002; accepted: July 11, 2002.

\section{Introduction}

Gasteropelecidae is a small fish family composed of three genera and eight species, all of small size (Gery, 1977). There are few cytogenetic data available for the group. The species Carnegiella strigata has $\mathrm{n}=25-26$ chromosomes according to Hinegardner and Rosen (1972), $\mathrm{n}=24$ chromosomes according to Scheel (1973), and $2 \mathrm{n}=48$ chromosomes according to Crychanã et al. (1996). The species Gasteropelecus sternicla has n $=27$ chromosomes (Scheel, 1973), and Thoracocharax stellatus has $2 \mathrm{n}=54$ chromosomes (Venere and Galetti Jr, 1996; Miyazawa, 1997). Studies about the amount of nuclear DNA showed that Carnegiella strigata and Gasteropelecus levis have 2.8 pg of DNA per diploid nucleus (Hinegardner and Rosen, 1972).

Most of the already karyotyped neotropical fishes do not have differentiated sex chromosomes. Only 51 species or local populations $(5.75 \%$ of all species analyzed) have sex chromosome systems, with 36 cases of female heterogamety $(68 \%)$ and 17 cases of male heterogamety (32\%) (Oliveira et al., 2000). Studies by Andreata et al.

Send correspondence to C. Oliveira. Departamento de Morfologia, Instituto de Biociências, Universidade Estadual Paulista, 18618-000 Botucatu, SP, Brazil. E-mail: claudio@ibb.unesp.br.
(1992, 1993), Moreira-Filho et al. (1993), and Bertollo et al. (2000) showed that species with different sex chromosome systems can be found in some taxonomic groups. The present study describes the karyotype of Thoracocharax cf. stellatus, showing that this species has a ZZ/ZW sex chromosome system.

\section{Materials and Methods}

Cytogenetic analyses were performed on 12 specimens ( 7 females and 5 males) of Thoracocharax cf. stellatus collected in the São Francisco stream, Rio Branco, Acre, Brazil. The fishes were identified and deposited in the fish collection of the Laboratory for Fish Biology of the Department of Morphology of the Institute of Biosciences (Laboratório de Biologia de Peixes, Departamento de Morfologia, Instituto de Biociências), UNESP, Botucatu, SP, Brazil (LBP 192).

Chromosome preparation and staining followed the techniques described by Foresti et al. (1993). At least 30 metaphases were analyzed for each specimen. Chromosome morphology was determined based on arm ratios, as proposed by Levan et al. (1964). Nuclear DNA content was determined according to Carvalho et al. (1998). 


\section{Results}

The modal diploid number of Thoracocharax cf. stellatus was $2 \mathrm{n}=52$ chromosomes for both sexes. The male karyotype was composed of 8 metacentric, 16 submetacentric, 4 subtelocentric, and 24 acrocentric chromosomes (Figure 1). In the female karyotype, there was only one chromosome number 11 (SM), identified as the $\mathrm{Z}$ chromosome. In addition to this, the female karyotype showed an exclusive acrocentric chromosome, smaller than all the others, identified as the $\mathrm{W}$ chromosome (Figure 1). Actually, the $\mathrm{Z}$ chromosome could not be clearly identified by the methods employed in this study, so they were tentatively considered as pair number 11 .

The nucleolus organizer regions (NORs) were observed on the short arm of pair 13 (ST), displaying a large size polymorphism (Figure 1). The constitutive heterochromatin was distributed over all the chromosomes, mainly in pericentromeric and terminal positions. The short arms of the chromosomes of pair 6 were almost entirely heterochromatic. The $\mathrm{W}$ chromosome was heterochromatic throughout almost all its extension, except for a small terminal segment, which was euchromatic (Figure 2).

The analysis of the amount of nuclear DNA from 4 specimens ( 3 females and 1 male) showed that the females had $2.17 \pm 0.09 \mathrm{pg}$ of DNA per diploid nucleus, and the male had $2.22 \pm 0.02$ pg of DNA per diploid nucleus, so there was no significant difference between sexes. The mean value for the species was $2.18 \pm 0.09 \mathrm{pg}$ of DNA per diploid nucleus.

\section{Discussion}

The presence of $2 \mathrm{n}=52$ chromosomes in Thoracocharax cf. stellatus constitutes a new finding for this genus, since previous studies conducted on two local populations of Thoracocharax stellatus from the Araguaia river, Amazon basin (Venere and Galetti Jr., 1996), and from the São Bento river, Paraná-Paraguay basin
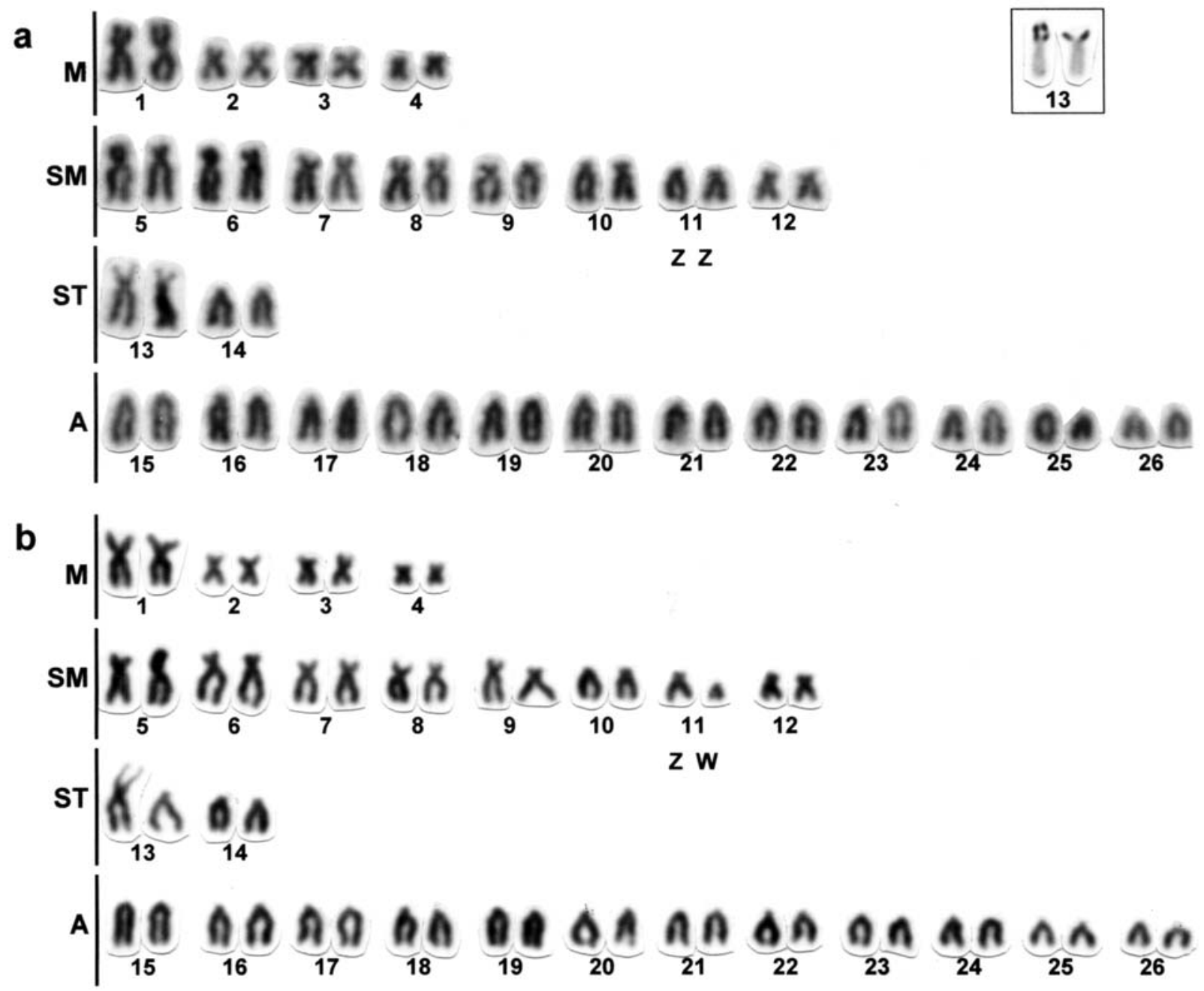

Figure 1 - Karyotypes of Thoracocharax cf. stellatus. (a) male; (b) female. The sex chromosomes are indicated (ZZ and ZW). In the inset, the NOR-bearing pair. 


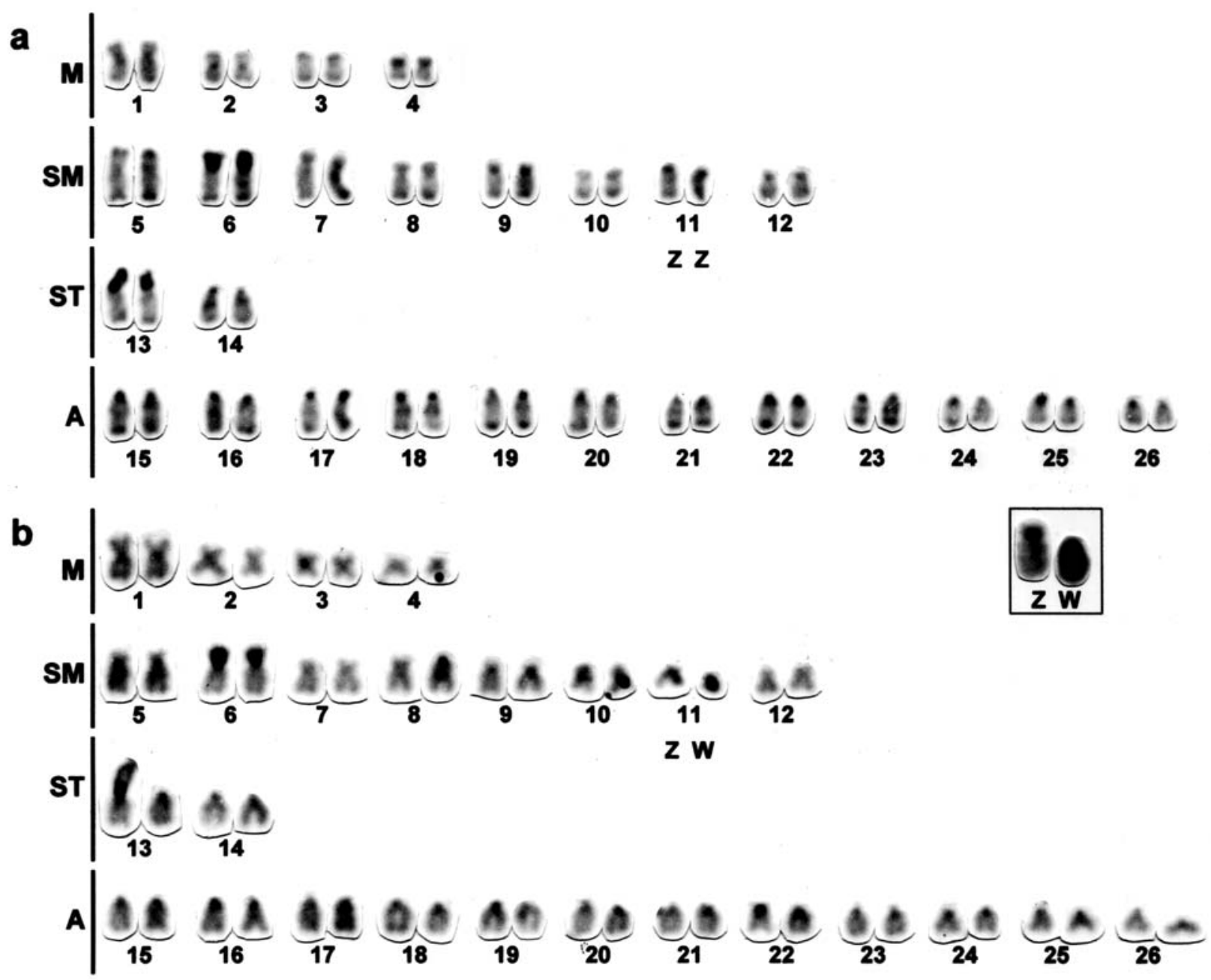

Figure 2 - Karyotypes of Thoracocharax cf. stellatus stained according to the C-banding technique. (a) male; (b) female. The sex chromosomes are indicated. In the inset, a detail of the ZW sex chromosomes.

(Miyazawa, 1997), showed the presence of $2 n=54$ chromosomes and different karyotypic constitutions. The different diploid numbers found in Thoracocharax stellatus suggest the existence of two different species, corroborating the results of preliminary morphological studies (Dr. Heraldo A. Britski, personal communication).

The occurrence of a large number of subtelocentric and acrocentric chromosomes in the karyotype is a common characteristic in the family Gasteropelecidae, also observed in this study. However, this fish group is characterized by the occurrence of a non-conservative karyotype, with a diploid number ranging from $2 \mathrm{n}=48$ to $2 \mathrm{n}=52$ chromosomes (Hinegardner and Rosen, 1972; Scheel, 1973; Crychanã et al., 1996; Venere and Galetti Jr., 1996; Miyazawa, 1997; present study).

The NORs were identified on the short arms of a subtelocentric chromosome pair in T. cf. stellatus, while in $T$. stellatus they were identified in a terminal position on the long arms of an acrocentric chromosome pair (Venere and Galetti Jr., 1996; Miyazawa, 1997). Thus, these data support the existence of a karyotypic differentiation among these samples and the hypothesis that they belong to different species.

The comparative study between the male and the female karyotypes of $T$. cf. stellatus showed that, while, in the males, pair 11 is composed of two subtelocentric chromosomes, in the females there is only one element similar to this pair, plus one small acrocentric chromosome not found in the males. These findings suggest the existence of a $\mathrm{ZZ/ZW}$ sex chromosome system in this species, the Z chromosome being submetacentric, and the $\mathrm{W}$ a small acrocentric chromosome. The presence of a sex chromosome system in $T$. cf. stellatus reinforces the evidence of a divergent karyotypic evolution in this group.

Although most neotropical fish species do not have differentiated sex chromosomes, some other kinds of sex chromosome systems were already described in some families (Andreata et al., 1992, 1993; Moreira Filho et al., 1993). In certain groups, such as some species of Anostomidae (Galetti Jr. and Foresti, 1986) and Triportheinae (Artoni, 1999), only the ZZ/ZW system was identified, while in other groups, such as Parodontidae and Erythri- 
nidae, different sex chromosome systems were detected (Moreira Filho et al., 1993). Among the Gasteropelecidae, only $T$. cf. stellatus has differentiated sex chromosomes (present study), while all other species studied are homomorphic with regard to sex chromosomes. These results support the hypothesis of the differentiation of sex chromosomes in fishes having occurred independently in different groups (Almeida-Toledo et al., 2000).

The first hypothesis proposed to explain the evolution of the sex chromosomes in vertebrates suggests that the differentiation of these chromosomes seems to have occurred firstly by structural rearrangements, resulting in a system that avoids the meiotic crossing-over between homologues. These rearrangements may have been followed or not by processes of heterochromatinization, with possible loss or gain of genetic material by one of the original homologues. Another hypothesis suggests an initial accumulation of satellite DNA in one homologue of a chromosome pair, leading to a heterochromatinization process and to the consequent morphological differentiation of the sex chromosomes (Ray-Chaudhuri et al., 1971; Singh et al., 1980).

The evolutionary process of the sex chromosomes seems to follow independent models in different fish groups. Thus, in some species of Poecilidae (Haaf and Schmid, 1984; Sola et al., 1990; Nanda et al., 1990) and of Hypoptopomatinae (Andreata et al., 1992; Andreata et al., 1993), the cytological differentiation of the sex chromosomes appears to be limited to the accumulation of heterochromatic segments. This process probably gave origin to the Y chromosome in Pseudotocinclus tietensis (Andreata et al., 1992), and to the W chromosome in Microlepidogaster leucofrenatus (Andreata et al., 1993), both species belonging to the subfamily Hypoptopomatinae (Loricariidae). In other cases, such as in the genus Leporinus (Galetti Jr. and Foresti, 1986), an initial heterochromatinization seems to have been followed by a process of accumulation of heterochromatic segments, with the consequent increase in size of the sex chromosome $\mathrm{W}$ in relation to the original homologues. In contrast, in the genus Triportheus, the heterochromatinization of the $\mathrm{W}$ chromosome was associated with a reduction of its size during the evolution of the ZW sex system (Falcão, 1988; Bertollo and Cavallaro, 1992). In T. cf. stellatus, a similar process seems to have occurred. Indeed, considering that in this species the putative $\mathrm{Z}$ chromosome has a small amount of constitutive heterochromatin, and that the $\mathrm{W}$ chromosome is almost entirely heterochromatic and the smallest in the complement, both a heterochromatinization process and a loss of genetic material are involved in the differentiation of this chromosome.

The analyses of the amount of nuclear DNA in the Gasteropelecidae showed that the species Carnegiella strigata and Gasteropelecus levis had 2.8 pg of DNA per diploid nucleus (Hinegardner and Rosen, 1972). This value is similar to that found for $T$. cf. stellatus, $2.18 \pm 0.09 \mathrm{pg}$ of
DNA per diploid nucleus, suggesting that only small changes in the amount of nuclear DNA were fixed during the evolutionary process of this group.

Based on morphological evidence, Eigenmann (1910) suggested that the fishes of the family Gasteropelecidae could constitute the sister group of Triportheinae and Cynodontidae. On the other hand, Weitzman (1960), suggested that the morphological similarity among Gasteropelecidae, Triportheinae, and Cynodontidae might represent only an adaptive convergence. The presence of a ZZ/ZW sex chromosome system in $T$. cf. stellatus and in the species of Triportheinae (Artoni, 1999) supports the existence of some kind of relationship between these groups.

The cytogenetic study of other species and/or populations of Gasteropelecidae will be very important for the establishment of the evolutionary relationships inside the group, and for a better understanding of the origin of differentiated sex chromosomes in this fish family.

\section{Acknowledgments}

The authors are grateful to Dr. Heraldo A. Britski for taxonomic identification of the specimens, to R. Devidé for technical assistance, to Dr. V. Dal Pai for the use of the microdensitometer, and to Drs. L.A.C. Bertollo, L. Giuliano-Caetano and C. Martins for their important suggestions concerning the original manuscript. Funds to support this study were provided by FAPESP, CAPES, CNPq, and FUNDUNESP.

\section{References}

Almeida-Toledo LF, Foresti F and Toledo-Filho SA (2000) Karyotypic evolution in Neotropical freshwater fish. Chrom Today 13:169-182.

Andreata AA, Almeida-Toledo LF, Oliveira C and Toledo-Filho SA (1992) Chromosome studies in Hypoptopomatinae (Pisces, Siluriformes, Loricariidae). I. XX/XY Sex chromosome heteromorphism in Pseudotocinclus tietensis. Cytologia 57:369-372.

Andreata AA, Almeida-Toledo LF, Oliveira C and Toledo-Filho SA (1993) Chromosome studies in Hypoptopomatinae (Pisces, Siluriformes, Loricariidae). II. ZZ/ZW sex-chromosome system, B chromosomes, and constitutive heterochromatin differentiation in Microlepidogaster leucofrenatus. Cytogenet Cell Genet 63:215-220.

Artoni RF (1999) Citogenética do sistema de cromossomos sexuais ZZ/ZW no gênero Triportheus (Pisces, Characidae). $\mathrm{PhD}$. Thesis. Universidade Federal de São Carlos, São Paulo.

Bertollo LAC, Born GG, Dergam JA, Fenocchio AS and Moreira-Filho O (2000) A biodiversity approach in the neotropical Erythrinidae fish, Hoplias malabaricus. Karyotypic survey, geographic distribution of cytotypes and cytotaxonomic considerations. Chrom Res 8:603-613.

Bertollo LAC and Cavallaro ZI (1992) A highly differentiated ZZ/ZW sex chromosome system in a Characidae fish Triportheus guentheri. Cytogenet Cell Genet 60:60-63. 
Carvalho ML, Oliveira C and Foresti F (1998) Nuclear content of thirty species of neotropical fishes. Genet Mol Biol 21:4754.

Crychanã SRL, Falcão JN, Feldberg E and Porto JIR (1996) Caracterização citogenética de três espécies de peixes ornamentais da Bacia Amazônica. VI Simpósio de Citogenética Evolutiva e Aplicada de Peixes Neotropicais, pp 13, São Carlos, São Paulo, Brazil.

Eigenmann CH (1910) Catalogue of the freshwater fishes of tropical and south temperate America. III Zoology. Reports of the Princeton University Expeditions to Patagonia, 18961899. Princeton, pp 375-511.

Falcão JN (1988) Caracterização cariotípica em peixes do gênero Thriportheus (Teleostei, Characiformes, Characidae). PhD. Thesis. Universidade de São Paulo, São Paulo, Brazil.

Foresti F, Oliveira C and Almeida-Toledo LF (1993) A method for chromosome preparations from large specimens of fishes using in vitro short treatment with colchicine. Experientia 49:810-813.

Galetti Jr. PM and Foresti F (1986) Evolution of the ZZ/ZW system in Leporinus (Pisces, Anostomidae). Cytogenet Cell Genet 43:43-46.

Gery J (1977). Characoids of the world. Neptune City, New Jersey. T.F.H. Publications, 672 pp.

Haaf T and Schimid M (1984) An early stage of ZW/ZZ sex chromosome differentiation in Poecilia sphenops var. melanistica (Poeciliidae, Cyprinodontiformes). Chromosoma 89:37-41.

Hinegardner R and Rosen DE (1972) Cellular DNA content and evolution of teleostean fishes. Amer. Nat. 106:621-644.

Levan A, Fregda K and Sandberg AA (1964) Nomenclature for centromeric position on chromosomes. Hereditas 52:201220.

Miyazawa CS (1997) Citogenética de caracídeos da bacia do rio Paraguai: Análises citotaxonômicas-evolutivas e conside- rações biogeográficas. $\mathrm{PhD}$. Thesis. Universidade Federal de São Carlos, São Paulo, Brazil.

Moreira-Filho O, Bertollo LAC and Galetti Jr. PM (1993) Distribution of sex chromosome mechanisms in neotropical fish and description of a ZZ/ZW system in Parodon hilarii (Parodontidae). Caryologia 46:115-125.

Nanda I, Feichtinger W, Schmid M, Schroder JH, Zischler H and Epplen JF (1990) Simple repetitive sequences are associated with differentiation of the sex chromosome in guppy fish. $\mathrm{J}$ Mol Evol 30:456-462.

Oliveira C, Almeida-Toledo LF and Foresti F (2000) Revisão dos estudos citogenéticos em peixes neotropicais de águas continentais. Proceedings of the VIII Simpósio de Citogenética e Genética de Peixes, pp 24, Manaus, Amazonas, Brazil.

Ray-Chaudhuri SR, Singh L and Sharma T (1971) Evolution of W-chromatin in snakes. Chromosoma 33:239-251.

Scheel JJ (1973) Fish chromosomes and their evolution. Internal Report of Danmarks Akvarium, Charlottenlund, Denmark, $22 \mathrm{pp}$.

Singh L, Purdon IF and Jones KW (1980) Sex chromosome associated satellite DNA: evolution and conservation. Chromosoma 79:137-137.

Sola L, Monaco PJ and Rasch EM (1990) Cytogenetics of bisexual/ unisexual species of Poecilia. I. C- Bands, Ag-NOR polymorphism, and sex chromosomes in three populations of Poecilia latipinna. Cytogenet Cell Genet 53:148-154.

Venere PC and Galetti Jr. PM (1996) O cariótipo de Thoracocharax stellatus (Pisces, Gasteropelecidae) e considerações sobre o filogenia do grupo. VI Simpósio de Citogenética Evolutiva e Aplicada de Peixes Neotropicais, pp 24, São Carlos, São Paulo, Brazil.

Weitzman SH (1960) The phylogenetic relationships of Triportheus, a genus of South American characid fishes. Stanf Ichth Bull 7:239-243. 